\title{
Physiological and Immunological Disturbance in Rheumatoid Arthritis Patients
}

\author{
Firas Faris Rija ${ }^{1}$ \\ Sura Zahim Hussein ${ }^{2}$ \\ Mohammad Ahmad Abdalla ${ }^{3 *}$ \\ ${ }^{1}$ Department of Biology, College of Sciences, Tikrit University, Tikrit, Iraq. \\ ${ }^{2}$ Salah Aldeen Health Directorate, Clinical Biochemistry Unit, Tikrit, Iraq. \\ ${ }^{3}$ Department of Human Anatomy, College of Medicine, Tikrit University, Tikrit, Iraq. \\ *Corresponding author: firas_tucon@tu.edu.iq, dr.sura2012@yahoo.com,dr.mohammad68@tu.edu.iq* \\ *ORCID ID: https://orcid.org/0000-0002-6325-5241,https://orcid.org/0000-0003-3643-5834, https://orcid.org/0000- \\ $0001-8122-3692$
}

Received 27/6/2020, Accepted 30/12/2020, Published Online First 11/1/2021, Published 1/6/2021

This work is licensed under a Creative Commons Attribution 4.0 International License.

\begin{abstract}
:
Rheumatoid arthritis (RA) is a systematic autoimmune disorder with chronic inflammation changes of unknown etiology. Various synovial inflammatory and proliferative alterations may contribute to the cartilaginous tissues and invasive bony tissues, leading to destructive joints and malformed bones. This disease is mostly due to infective microorganisms or genetic susceptibility causing immune system disturbances through triggering both T-cells and B-cells. Furthermore, different immune cells may secret cytokines, which are responsible for some RA pathogenesis activity. From ninety individuals, serum sample was collected; thirty of them were normal and sixty cases were patients with RA attended a privet medical clinic at Tikrit city from May 2019 to November 2019. Age, in both patients and control groups, ranged between (18-50) years, they had assay of Interleukin-1 (IL-1), Interleukin-6 (IL-6), Interleukin-10 (IL-10), Tumor necrosis factor (TNF)- $\alpha$, Leptin, Adiponectin, and C-reactive protein. The present study shows that (IL-1, Leptin, and CRP) levels were higher in Rheumatoid Arthritis patients than control, while (IL-6, IL-10, $\mathrm{TNF} \alpha$, and ADP) levels were lower; therefore, cytokines can play an essential role in RA pathogenesis. The current study may bring attention to adiponectin and leptin for their roles in the pathogenesis of RA. Special consideration was devoted to those proteins, which act on cells associated with RA, also for possible usage of these protein levels as potential biomarkers for the disease activity and therapeutic response.
\end{abstract}

Keywords: Adiponectin (ADP), C-reactive protein (CRP), Cytokines, Leptin, Rheumatoid Arthritis (RA), Tumor Necrosis Factor-Alpha (TNF- $\alpha$ ).

\section{Introduction:}

Rheumatoid Arthritis (RA) is regarded as a chronic inflammatory autoimmune disorder affecting females more than males with predominant observation in old people; its prevalence ranges between $(0.5-1) \%$ from the total community population with regional varieties (1).

RA initially affects the synovial joint linings leading to progressive disabilities and social burdens. Oedema, erythema, arthralgia with movement range limitations are the cardinal clinical joint features with symmetrical involvement. Early RA diagnosis may be regarded as the key index for the improvement of the most expected fate of the disease including less destructive joints, few progressive radiological findings, absent functional disabilities with Disease Modifying Anti-Rheumatic Drugs (DMARD) free-remission; in addition to

cost-efficiency in the first twelve weeks after the appearance of early clinical symptoms which are considered as an optimal therapeutic window $(2,3)$.

Although, early diagnosis is still a challenge since it mainly depends upon the clinical data collected from the patient's history with physical examinations; in association with specific blood tests and radiological images. The Poor healthcare system in some countries causes delayed diagnosis of RA (4).

RA has two major subtypes regarding the anti-citrullinated protein antibodies (ACPAs) presence or absence. Peptidylarginine-deaminase (PAD) is a calcium-dependent enzyme that catalyzes citrullination and alters the positivecharged arginine into neutral citrulline due to a specific post-translational modification process. ACPAs were found in about $67 \%$ of RA patients 
which is regarded as an important diagnostic finding for the appearance of early arthritis that indicates the disease progression likelihood to RA $(5,6)$.

IL-1 is a pro-inflammatory cytokine with immune activities. IL-1RI and IL-1RII are two specific receptors identified for IL-1. IL-RII is located at the cell surfaces acting as a decoy receptor, which binds and inhibits IL-1. On contrary, in serum the IL-1 receptors may bind IL-1 leading to regulate cytokine bioavailability $(7,8)$. Different cell types like B-cells, T-cells, fibroblasts, monocytes, synovial and endothelial cells produce IL-6 (9).

Leptin is regarded as a superfamily member of type I cytokine; with a long-helix structure that resembles interleukin IL-2 and IL-6 (10). It may play a role to regulate the metabolic processes as well as controlling the immune homeostasis, which eventually causes diverse actions onto the innate immune system. In addition, leptin may serve as a pro-inflammatory cytokine of the immune responses in some diseases like psoriasis, multiple sclerosis (MS), RA, and systemic lupus erythematosus (SLE) (11-13).

Adiponectin is considered as a collagen-like protein, which has the same structure as complement factor C1q. It is mostly produced by adipocytes and exists in various molecular isoforms and with high levels in the blood. The principal functions of adiponectin include increasing the fatty acid oxidation with the glucose uptake in the muscle while decreasing the glucose synthesis in the liver (14).

\section{Materials and Methods:}

Venous blood of about (5-10) $\mathrm{ml}$ was taken from Rheumatoid Arthritis patients and control subjects; it was allowed to clot inside a plain tube. After doing centrifugation for 30 minutes at 3000 $\mathrm{rpm}$, the serum was aspirated, then subdivided into aliquots within plastic tubes and kept at $\left(-20^{\circ} \mathrm{C}\right)$ till the time of estimation.

From ninety individuals, serum sample was collected; thirty of them were normal and sixty cases were patients with Rheumatoid Arthritis who attended to a private medical clinic in Tikrit city from May 2019 to November 2019. Patients and control groups were between (18-50) years. All the control persons were non-diabetics and nonsmokers with neither a familial history of diabetes nor a personal history of hypertensive, thyroid, or renal diseases.
Immunological assays including IL-1, IL-6, IL-10, CRP, TNF $\alpha$, Leptin, and Adiponectin, estimated by using Enzyme Linked Immunosorbent Assay (ELISA) Sunlong Biotech Company kits with the sandwich method (15).

Statistical analysis was done by using SPSS, 2001 statistical program, and a comparison was made between various groups, which were evaluated by t-test. The level of statistical significance was calculated at $(\mathrm{P}<0.05)$.

\section{Results:}

The results of the current study illustrated that the mean $\pm \mathrm{SD}$ of interleukins levels were (IL-1 = $57.72 \pm 11.85$, IL- $6=6.35 \pm 1.28$ and IL- $10=$ $36.9 \pm 15.84) \mathrm{pg} / \mathrm{ml}$ respectively in the RA patients group with highly significant difference $(\mathrm{P} \leq 0.01)$ when compared with normal subjects (IL-1= $34.5 \pm 8.5$, IL- $6=15.80 \pm 10.32$ and $\mathrm{IL}-10=$ $110.5 \pm 40.5) \mathrm{pg} / \mathrm{ml}$ respectively.

Serum TNF- $\alpha$ in the RA patients group was $(143.57 \pm 27.38) \mathrm{pg} / \mathrm{ml}$ with a significant decrease $(\mathrm{P} \leq 0.05)$ when compared with normal subjects (358 \pm 212.13$) \mathrm{pg} / \mathrm{ml}$.

Leptin level was $(253.75 \pm 158.7) \mathrm{ng} / \mathrm{ml}$ in RA patients group with no significant increase $(\mathrm{P}>0.05)$ when compared with normal subjects $(160 \pm 28.49) \mathrm{ng} / \mathrm{ml}$.

ADP level in the RA patients group was $(1.6 \pm 0.18) \mathrm{ng} / \mathrm{ml}$ with a highly significant decrease $(\mathrm{P} \leq 0.01)$ when compared with normal subjects $(5.2 \pm 2.57) \mathrm{ng} / \mathrm{ml}$.

CRP level was $(10.2 \pm 5.5) \mathrm{mg} / \mathrm{l}$ in the RA patients group with a highly significant increase $(\mathrm{P} \leq 0.01)$ when compared with normal subjects $(4.2 \pm 0.86) \mathrm{mg} / \mathrm{l}$.

All the above results are shown in Table 1,

Figs. 1 and 2.

Table 1. Serum Levels of all studied parameters in Rheumatoid Arthritis patients and control groups.

\begin{tabular}{cccc}
\hline Parameters & $\begin{array}{c}\text { Rheumatoid } \\
\text { Arthritis patients }\end{array}$ & $\mathrm{P}$ value & Control \\
\hline Number of & 60 & - & 30 \\
subjects & & - & $(18-50)$ \\
Age (year) & $(18-50)$ & $* \mathrm{P} \leq 0.01$ & $34.5 \pm 8.5$ \\
IL-1 pg/ml & $57.72 \pm 11.85$ & $* \mathrm{P} \leq 0.01$ & $15.80 \pm 10.32$ \\
IL-6 pg/ml & $6.35 \pm 1.28$ & $* \mathrm{P} \leq 0.01$ & $110.5 \pm 40.5$ \\
IL-10 pg/ml & $36.9 \pm 15.84$ & $* * \mathrm{P} \leq 0.05$ & $358 \pm 212.13$ \\
$\mathrm{TNF}-\alpha \mathrm{pg} / \mathrm{ml}$ & $143.57 \pm 27.38$ & $* * * \mathrm{P}>0.05$ & $160 \pm 28.49$ \\
Leptin $\mathrm{ng} / \mathrm{ml}$ & $253.75 \pm 158.7$ & $* \mathrm{P} \leq 0.01$ & $5.2 \pm 2.57$ \\
$\mathrm{ADP} \mathrm{ng} / \mathrm{ml}$ & $1.6 \pm 0.18$ & $* \mathrm{P} \leq 0.01$ & $4.2 \pm 0.86$ \\
$\mathrm{CRP} \mathrm{mg} / \mathrm{l}$ & $10.2 \pm 5.5$ & \\
$* \mathrm{P} \leq 0.01=$ statistically highly significant \\
$* * \mathrm{P} \leq 0.05=$ statistically significant \\
$* * * \mathrm{P}>0.05=$ not statistically significant
\end{tabular}




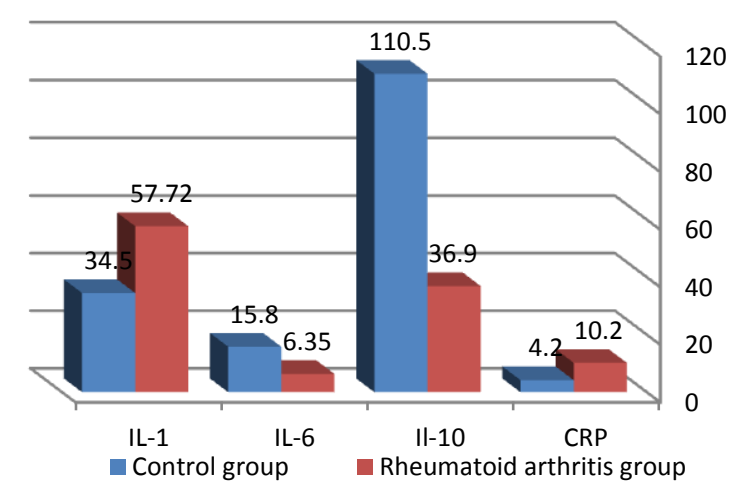

Figure 1. IL-1, IL-6, IL-10 and CRP levels in Rheumatoid Arthritis patients and control.

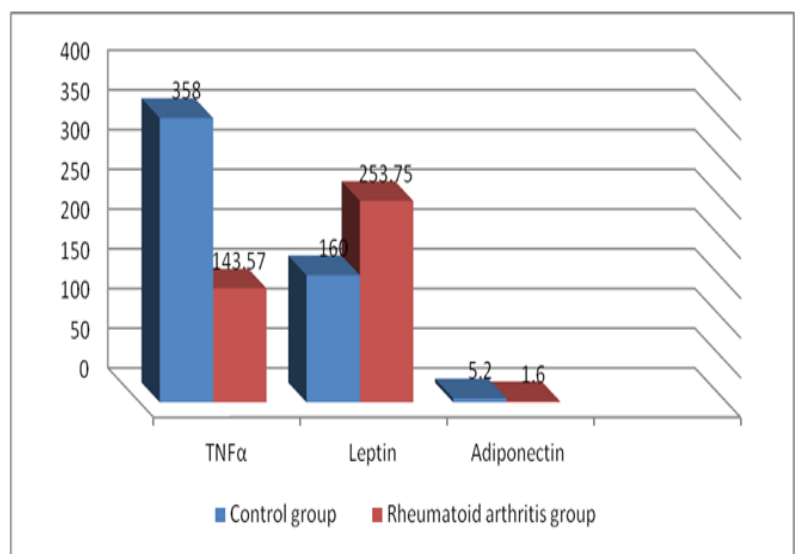

Figure 2. TNF $\alpha$, Leptin and Adiponectin levels in Rheumatoid Arthritis patients and control.

\section{Discussion:}

This study revealed that IL-1, Leptin, and CRP levels increased with a highly significant difference $(\mathrm{P} \leq 0.01)$ in the RA patients group rather than control; while the IL-6, IL-10, TNF $\alpha$, and ADP serum levels decreased with highly significant difference $(\mathrm{P} \leq 0.01)$.

Significant elevation in leptin serum levels of RA patients was obvious in some studies $(16,17)$; in contrast, others have found decreased levels (1820). However, leptin established a complicated relationship since it serves as a principal link factor between food intake and active bone metabolism as reported by Sandell (21) study.

Targonska-Stepniak et al (22) study carried out on RA in the erosive phase revealed a clear increment of leptin serum levels, which may indicate the down-regulation activity during the erosion of the joints. This finding was in agreement with the findings of the current study.

As leptin triggers the production for IL-1 receptor antagonists; therefore, RA patients treated with anakinra (IL-1 receptor antagonist) showed excellent toleration leading to protect the joint from the destruction and erosion mentioned by the Planck study (23). On the other hand, leptin may trigger the production of CRP with a specific physiological role as reported by Ali et al (24). In RA patients, a weak association of CRP with leptin was reported through various studies (25-27); contrary to the current study findings, which showed that there is an increase in the levels of them in RA patients.

The present study revealed a decreased level of adiponectin in RA patients, which may be explained due to a potential activity of this cytokine in control of the inflammatory changes. This might occur through many mechanisms including inhibiting the macrophage cells' transformation into foam cells which were reported in a study done by Yang et al (28); or stimulation of IL-10 production as it well-defined cytokine of anti-inflammatory characteristics discovered by Conti et al (29) study. In addition, the reduction in TNF- $\alpha$ formation demonstrated by Greenblatt et al (30), or even induction of tolerance as an action for Toll-like receptor (TLR) ligands that reported by Turner et al (31), and promotion of the anti-inflammatory M2 macrophage cells polarization that proved by $\mathrm{Li}$ et al (32) study. Finally, alteration in ceramide metabolism with the promotion of sphingosine-1phosphate synthesis may explain the adiponectin anti-inflammatory activity in some cases studied by Hollet al (33).

Also, this study suggested the importance of the estimation of adiponectin serum levels and synovial fluid levels during the erosive phase of RA; this could explain its association with significant radiographical destructive injury as mentioned by Chan et al (34). While it showed high levels in comparison with osteoarthritis (OA) and even the healthy individuals as reviewed by Pontes et al (35) and Srivastavaand et al (36) studies respectively.

Although, Disease Activity Score 28 (DAS28), Rheumatoid Factor (RF), Erythrocyte Sedimentation Rate (ESR), revealed a positive relationship with high adiponectin levels through a report done by Bankó et al (37). However, the current study findings demonstrated that the baseline adiponectin serum level might expect the progressive radiographical changes of RA for several next years; with independency of increased anti-cyclic citrullinated peptide (ACCP) antibodies with body mass index (BMI).

On the other hand, the low level of TNF- $\alpha$ in RA of the present study might give an explanation to those RA patients treated with the most common biological agents like anti-TNF drugs (infliximab or etanercept) who also showed an increment in adiponectin serum level as described by Li et al (38). While, the current finding disagreed with a high TNF- $\alpha$ level in the inflammatory 
disorders of skeletal system, which might lead to conclude this cytokine influences the regional destructive bone processes that proved by Mendes et al (39), although a new proof indicates that TNF$\alpha$ antagonist agent can facilitate blood vessels stiffness in RA which reported by Mercer et al (40).

This study clarified a low level of IL-6 in the RA patients group compared to control, which could explain the disease pathogenesis. As a result of the pannus formation that may be stimulated by IL-6 through increasing vascular endothelial growth factor expression (VEGF-E) and increasing resorption of bones from osteoclastogenesis, in combination with oxidative stress within the leukocytes which mentioned by Gruol (41).

\section{Conclusion:}

TNF- $\alpha$, ADP, and Interleukins decreased markedly (except IL-1), but leptin and CRP increased among RA patients. RA is an autoimmune disorder; therefore, treatment with antiinflammatory drugs may decrease or inhibit some interleukins or cytokines.

\section{Authors' declaration:}

- Conflicts of Interest: None.

- We hereby confirm that all the Figures and Tables in the manuscript are mine ours. Besides, the Figures and images, which are not mine ours, have been given the permission for republication attached with the manuscript.

- Ethical Clearance: The project was approved by the local ethical committee in Tikrit University.

\section{References:}

1. Oton T, Carmona L. The epidemiology of established Rheumatoid Arthritis. Best Pract Res Clin Rheumatol. 2019;33(5):101477.

2. Strangfeld A, Richter A, Siegmund B, Herzer P, Rockwitz K, Demary W, et al. Risk for lower intestinal perforations in patients with Rheumatoid Arthritis treated with tocilizumab in comparison to treatment with other biologic or conventional synthetic DMARDs. Ann Rheumatol Dis.2017;76:504-10.

3. Ramiro S, Sepriano A, Chatzidionysiou K, Nam JL, Smolen JS, van der Heijde, et al. Safety of synthetic and biological DMARDs: a systematic literature review informing the 2016 update of the EULAR recommendations for management of Rheumatoid Arthritis. Ann Rheumatol Dis. 2017;76:1101-36.

4. Klaresgog L.Understanding and prevention of the evolution towards autoimmune Rheumatoid Arthritis: the new challenge. Clin Ther. 2019;41:1232-4.

5. Weyand CM, Goronzy JJ. Immunometabolism in early and late stages of Rheumatoid Arthritis. Nat Rev Rheumatol. 2017;13:291-301.
6. Wu C, Yang H, Lai J. Anti-Citrullinated Protein Antibodies in Patients with Rheumatoid Arthritis: Biological Effects and Mechanisms of Immunopathogenesis. Int J Mol Sci. 2020;21:4015.

7. Gallenga CE, Pandolfi F, Caraffa Al, Kritas SK, Ronconi G, Toniato E, et al. Interleukin-1 family cytokines and mast cells: activation and inhibition. J Biol Regul Homeost Agents. 2019;33:1-6.

8. Ruiz-Limón P, Ortega R, Arias de la Rosa I, AbalosAguilera MDC, Perez-Sanchez C, Jimenez-Gomez Y, et al. Tocilizumab improves the proatherothrombotic profile of Rheumatoid Arthritis patients modulating endothelial dysfunction, NETosis, and inflammation. Transl Res. 2017;183:87-103.

9. Navarro-Millan I, Singh JA, Curtis JR. Systematic review of tocilizumab for Rheumatoid Arthritis: a new biologic agent targeting the interleukin-6 receptor. Clin Ther. 2012;34:788-802.

10. Mercado MV, Martinez-Garcia EA. Leptin as an open secret in the physiopathology of Rheumatic disease. Clin Rheumatol. 2020;39:301-3.

11. Mosanya $\mathrm{CH}$, Isaacs JD. Tolerating cellular therapies: what is their promise for autoimmune disease? Ann Rheumatol Dis. 2019;78:297-310.

12. Otero M, Lago R, Lago F, Reino JJ, Gualillo O. Signalling pathway involved in nitric oxide synthase type II activation in chondrocytes: synergistic effect of leptin with interleukin-1. Arthritis Res Ther. 2005;7:581-91.

13. Wadström H, Frisell T, Askling J. Malignant neoplasms in patients with Rheumatoid Arthritis treated with tumor necrosis factor inhibitors, tocilizumab, abatacept, or rituximab in clinical practice. JAMA Intern Med. 2017;177:1605.

14.Ruscitti P, Benedetto P D, Berardicurti O, Giacomelli R. Adipocytokines in Rheumatoid Arthritis: The Hidden Link between Inflammation and Cardiometabolic Comorbidities. J Immun Res. 2018;1:1-10.

15.Sunlong Biotech Co. Human Elisa kit. Available from:

https://www.sunlongbiotech.com/gory.php?id=66. [Accessed 2 December 2020].

16.Petra CV, Vonica CL, Rahaian R, Rednic S, Vesa SC, Zdrenghea $\mathrm{M}$, et al. Circulating leptin and resistin levels in a Romanian Rheumatoid Arthritis population. Roman J Rheumatol. 2020;29(2):79-83.

17. Costello R, David T, Jani M. Impact of adverse events associated with medications in the treatment and prevention of Rheumatoid Arthritis. Clin Ther. 2019;41:1376-96.

18. Hayashi H, Satoi K, Sato-Mito N, Kaburagi T, Yoshino H, Higaki M, et al. Nutritional status in relation to adipokines and oxidative stress is associated with disease activity in patients with Rheumatoid Arthritis. Nutrition. 2012;28:1109-14.

19. Hazlewood GS, Bombardier C, Tomlinson G, Thorne C, Bykerk VP, Thompson A, et al. Treatment preferences of patients with early Rheumatoid Arthritis: a discrete-choice experiment. Rheumatol (United Kingdom). 2016;55:1959-68. 
20. Kunwar S, Collins CE, Constantinescu F. Baricitinib, a Janus kinase inhibitor, in the treatment of Rheumatoid Arthritis: a systematic literature review and meta-analysis of randomized controlled trials. Clin Rheumatol. 2018;37:2611-20.

21.Sandell LJ. Obesity and osteoarthritis: is leptin the link? Arthritis Rheumatol. 2009; 60: 2858-60.

22. Targonska-Stepniak B, Majdan M, Dryglewska M. Leptin serum levels in Rheumatoid Arthritis patients: relation to disease duration and activity. Rheumatol Int. 2008;28:585-91.

23.Planck SR, Woods A, Clowers JS, Nicklin MJ, Rosenbaum JT, Rosenzweig HL. Impact of IL-1 signalling on experimental uveitis and arthritis. Ann Rheumatol Dis. 2012;71(5):753-60.

24. Ali S, Hussein SZ, Hussain WN. Study of the Correlation between Serum C-reactive Protein and Bone Biochemical Markers in Type 2 Diabetic Individuals. Tikrit J Pure Sci. 2014;19(5):58-64.

25. Wang K, Chen L, Liu L, Cui Y, Zhang X, Jiang J. The effects of atorvastatin on IL-6, CRP, blood lipid and myocardial protection of interventional therapy in patients with acute myocardial infarction. Minerva Med. 2019;110:101-6.

26.Pozzi D, Menna M, Canzi A, Desiato G, Mantovani C, Matteoli M. The communication between the immune and nervous systems: the role of IL-1 $\beta$ in synaptopathies. Front Mol Neurosci. 2018;11:111.

27. Caraffa Al, Conti C, D Ovidio C, Gallenga CE, Tettamanti L, Mastrangelo F, et al. New concepts in neuroinflammation: mast cells pro-inflammatory and anti-inflammatory mediators. J Biol Regul Homeost Agents. 2018;32:1345-7.

28. Yang M, Haase C, Viljanen J, Xu B, Ge C, Kihlberg $\mathrm{J}$, et al. Cutting edge: processing of oxidized peptides in macrophages regulates $\mathrm{T}$ cell activation and development of autoimmune arthritis. J Immunol. 2017;199:3937-42.

29. Conti P, Caraffa A, Mastrangelo F, Tettamanti L, Ronconi G, Frydas I, et al. Critical role of inflammatory mast cell in fibrosis: potential therapeutic effect of IL-37. Cell Prolif. 2018;51:12475.

30. Greenblatt HK, Kim HA, Bettner LF, Deane KD. Preclinical Rheumatoid Arthritis and Rheumatoid Arthritis Prevention. Cur Opin Rheumatol. 2020;32(3):1-6.

31. Turner JJ, Smolinska MJ, Sacre SM, Foxwell BM. Induction of TLR tolerance in human macrophages by adiponectin: does LPS play a role? Scand J Immunol. 2009;69(4):329-36.

32.Li GM, Zhao J, Li B, Zhang XF, Ma JX, Ma XL, et al. The anti-inflammatory effects of statins on patients with Rheumatoid Arthritis: a systemic review and meta-analysis of 15 randomized controlled trials. Autoimmun Rev. 2018;17:215-25.

33. Holland WL, Miller RA, Wang ZV, Sun K, Barth $\mathrm{BM}$, Bui HH, et al. Receptor mediated activation of ceramidase activity initiates the pleiotropic actions of adiponectin. Nature Med. 2011;17(1):55-63.

34. Chan D, Goruk S, Becker AB, Subbarao P, Mandhane PJ, Turvey SE, et al. Adiponectin, leptin and insulin in breast milk: associations with maternal characteristics and infant body composition in the first year of life. Int J Obes (Lond). 2018;42:36-43.

35.Pontes C, Marsal JR, Elorza JM, Aragon M, PrietoAlhambra D, Morros R. Analgesic Use and Risk for Acute Coronary Events in Patients with Osteoarthritis: A Population-based, Nested Casecontrol Study. Clin Ther. 2018;40(2):270-83.

36. Srivastava SB, Fluegel N, Mansukhani RP. Pharmacologic Management of Rheumatoid Arthritis. Orthop Nurs. 2019;38(6):390-5.

37.Bankó Z, Pozsgay J, Gáti T, Rojkovich B, Ujfalussy I, Sármay G. Regulatory B cells in Rheumatoid Arthritis: alterations in patients receiving anti-TNF therapy. Clin Immunol. 2017;184:63-9.

38.Li N, Betts KA, Messali AJ, Skup M, Garg V. Realworld Effectiveness of Biologic Disease-modifying AntiRheumatolatic Drugs for the Treatment of Rheumatoid Arthritis After Etanercept Discontinuation in the United Kingdom, France, and Germany. Clin Ther. 2017;39(8):1618-27.

39. Mendes MT, Alponti RF, Alves PL, Trevizan IL, Markus RP, Fernandes PA, et al. Inhibitors of Tumor Necrosis Factor Synthesis as a New Approach for the Treatment of Rheumatoid Arthritis. J Arthritis. 2020;9(4):001-7.

40. Mercer LK, Galloway JB, Lunt M, Davies R, Low $\mathrm{AL}$, Dixon WG, et al. Risk of lymphoma in patients exposed to antitumour necrosis factor therapy: results from the British Society for Rheumatology Biologics Register for Rheumatoid Arthritis. Ann Rheumatol Dis. 2017;76:497-503.

41. Gruol DL. Impact of increased astrocyte expression of IL-6, CCL2 or CXCL10 in transgenic mice on synaptic function. Brain Sci. 2016;6:19. 
الاضطرابات الفسيولوجية والمناعية لدى مرضى إلتهاب المفاصل الرثوي

محمد أحمد عبدالله 3

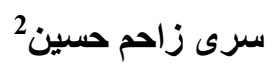

فراس فارس رجا1

1 1 قسم علوم الحياة كلية العلوم جامعة تكريت، تكريت، العراق.

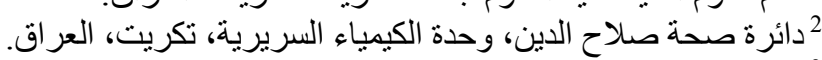

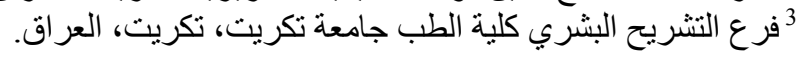

الخلاصة:

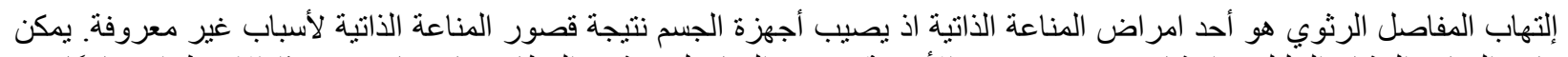

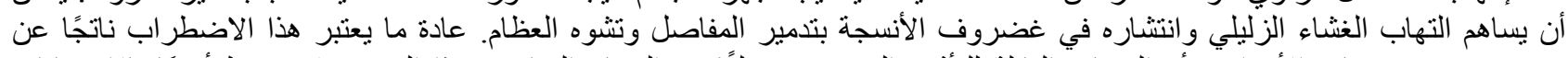

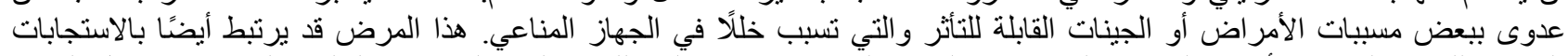

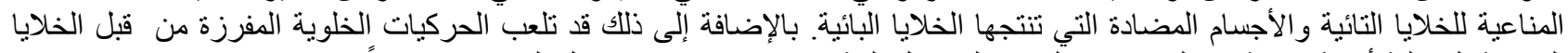

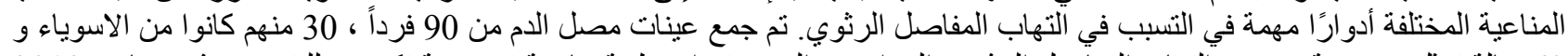

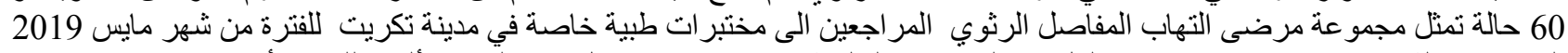

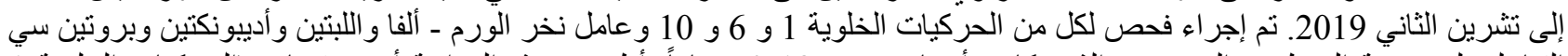

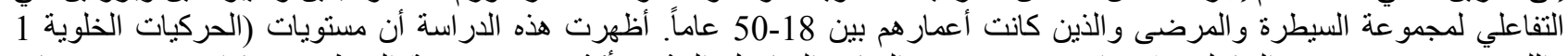

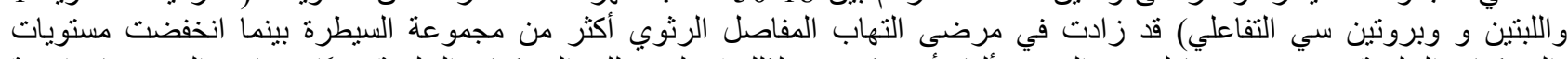

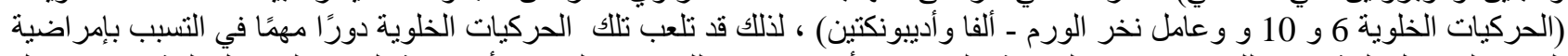

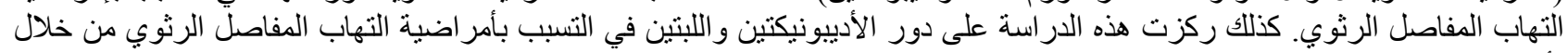

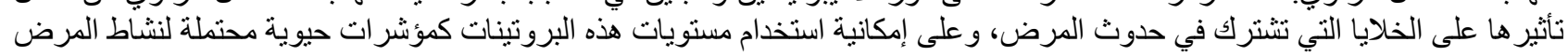
و استجابة المرضى للعلاج.

الكلمات المفتاحية:أديبونكتين، بروتين سي التفاعلي، الحركيات الخلوية، لبتين، إلتهاب المفاصل الرثوي، عامل نخر الورم ـ ألفا. 